MAREK KOSMA CIEŚLIŃSKI

Wyższa Szkoła Handlowa we Wrocławiu
Images

vol. XXVII/no. 36

Poznań 2020

ISSN 1731-450X

\title{
Destrukcja jako tworzywo. Ikonografia ruin Warszawy $w$ polskim kinie dokumentalnym po II wojnie światowej
}

\begin{abstract}
Aвstract. Cieśliński Marek Kosma, Destrukcja jako tworzywo. Ikonografia ruin Warszawy w polskim kinie dokumentalnym po II wojnie światowej [Destruction as a material. Iconography of the ruins of Warsaw in Polish documentary cinema after the Second World War]. "Images" vol. XXVII, no. 36. Poznań 2020. Adam Mickiewicz University Press. Pp. 169-181. ISSN 1731-450X. DOI 10.14746/i.2020.36.11.

The image of Warsaw in ruins after World War II is an important motif in Polish documentary and feature cinema in the years 1944-1956. In the text, I discuss the images of the city captured by the first chroniclers as 'basic', which then became archetypical icons of the city's destruction. I point out that the aesthetics of destruction, recorded in Andrzej Panufnik's early film Ballada f-moll [Ballade in f minor], Jerzy Bossak's Most [Bridge] and Tadeusz Makarczyński’s Suita warszawska [Warsaw Suite] proved to be exemplary for other artists. I show that the destruction of urban and architectural structures was inspiring for directors: it served as a documentary record, a basis for constructing scripts, and dominant aesthetic, often providing a persuasive argument and serving to shape emotions. References to the resentments of the audience and the anatomy of the ruins were among the elements that shaped the ideological attitudes of various parts of Polish society. For some directors it was also a catharsis after the trauma of the Holocaust.
\end{abstract}

KEYWORDS: Iconography of ruins, World War II, Warsaw, destruction, creation

Kilka pierwszych powojennych dokumentów polskiego kina łączy tematyka zniszczonej Warszawy. Jest ona dominantą wyznaczającą kompozycję nie tylko tych najwcześniejszych tytułów, ale również kształtującą późniejsze prezentowanie motywów architektonicznej destrukcji. W niniejszym artykule wskażę możliwe tropy wpływu ikonografii ruin na wybrane filmy dokumentalne.

Punkt wyjścia stanowią rejestracje operatorów Czołówki Filmowej Wojska Polskiego, przemieszczających się razem z linią frontu i dokumentujących zniszczenia w wyzwalanych miastach. Ważne są tu dwa reportaże Polskiej Kroniki Filmowej. PKF 9,10/45 zatytułowana Bitwa o Kołobrzeg jest 14-minutową relacją z zaciętych walk o bałtycki port, w której wiele obrazów przedstawia zdeformowaną substancję urbanistyczną (komentarz: Na tych gruzach zbudujemy nowe miasto). Z kolei PKF 15,16,17/45, znana jako Zagłada Berlina, przedstawia sceny zwycięstwa (Miażḋ̇y Trzecią Rzeszę opancerzona pięść Armii Czerwonej). Uszkodzone kamienice, płonące budynki, dymy nad kwartałami bloków - takie obrazy dominują. Są ikonami długo oczekiwanymi, przynoszącymi poczucie dziejowej sprawiedliwości i nadzieję na po- 
wrót do życia. Inicjują też nową retorykę opisywania rzeczywistości, budowanej teraz na gruzach, na zgliszczach faszyzmu.

Istotne dla sprawy jest wojenne doświadczenie operatorów PKF. Niektórzy z nich rejestrowali klęskę Warszawy we wrześniu 1939 roku (Jerzy Zarzycki, Wacław Kaźmierczak, Roman Banach), inni dokumentowali walki powstania warszawskiego (oprócz wspomnianych także między innymi Antoni Bohdziewicz, Seweryn Kruszyński, Antoni Wawrzyniak). Jedni i drudzy zapisywali na taśmie rozpad architektonicznej tkanki dużego europejskiego miasta, dewastację form estetycznych, rozbijanie struktur różnych wytworów budownictwa i zagładę kulturowego dorobku pokoleń. Dla nich, wyczulonych na fotogenię, uchwycone kadry zniszczenia stawały się archetypicznymi znakami reprodukcji obserwowanego świata. Budowały ich wrażliwość, rozumienie procesu dziejowego i wskazywały inspiracje twórcze. Zaowocuje to obfitą dokumentacją zdjęciową. Po latach Jerzy Bossak, ówczesny szef Polskiej Kroniki Filmowej, potwierdzi: „Wiedzieliśmy oczywiście, że pejzaż warszawski - ten z roku 1945 - zniknie nieodwracalnie, ale nasze filmy i tematy kronikalne pozostaną świadectwem czasu, który był dla Warszawy rokiem zerowym" [1].

Ikonografia pierwszych powojennych miesięcy okazuje się istotna także dzisiaj. Polemizując z modelami uprawiania historiozofii opartej bardziej na świadectwach werbalnych lub ikonicznych niż na wiarygodności opisu niegdysiejszych zdarzeń, Hayden White w tekście Historiografia i historiofotia zauważył:

Żadna historia, ani wizualna, ani werbalna, nie stanowi „lustrzanego odbicia" całości lub choćby większej części wydarzeń czy miejsc, które ma przedstawiać. To stwierdzenie dotyczy nawet najbardziej skupionej na detalu „mikrohistorii”. Każda historia pisana powstaje w efekcie kondensacji, przeniesienia, symbolizacji oraz selekcji: są to dokładnie te same procesy, które decydują o kształcie reprezentacji filmowej[2].

Zatem historiofotia, a więc podążanie głównie za ikonicznymi reprezentacjami zdarzeń, może sprowadzić nas - odbiorców szukających najlepszej możliwej historiozoficznej narracji o śladach przeszłych - na manowce. Może się bowiem okazać, że niektóre z filmowych wypowiedzi to tylko kalki archetypicznych wyobrażeń.

By zrozumieć optykę świadka kraju ruin, cofnę się do doświadczeń z 1945 roku. 3 maja w stołecznym Muzeum Narodowym została otwarta wystawa „Warszawa oskarża”, obejmująca rysunki, akwarele, gwasze i fotografie dokumentujące na gorąco impresje z miasta obróconego wniwecz, zniszczonego prawie w całości. Otwarta z udziałem prezydenta i premiera, spotkała się z olbrzymim zainteresowaniem publiczności. Stanisław Gebethner tak tłumaczył intencje kuratorów: „Wystawa była jakimś spontanicznym odruchem i protestem prze-

[1] J. Bossak (wypow.), Ab urbe condita..., „Film” 1980 , nr 3 .
[2] H. White, Historiografia i historiofotia, przeł.

Ł. Zaremba, [w:] Film i historia. Antologia, red.

I. Kurz, Warszawa 2008, s. 117-127. 
ciwko barbarzyństwu najeźdźcy. Nie była ona jakąś akcją zaplanowaną i obmyśloną zawczasu, wykonywaną systematycznie" [3]. W deklaracji programowej dotyczącej ekspozycji napisano: „Celem wystawy nie było stać się jeszcze jednym pokazem cierpiętnictwa narodowego, panopticum okropności, utrwalającym to, co miasto jako organizm żywy od trzech miesięcy regeneruje, oczyszczając i gojąc rany. Zadaniem naszym jest obiektywizacja przeżyć, ukazanie w chaosie ruin sensu katastrofy, ujawnienie intencji wroga" [4]. Exposé bardzo przydatne i zachęcające do szukania motywacji także dla dokumentu filmowego.

Motyw powojennych ruin Warszawy to temat ponadczasowy, który jest stale opracowywany, udostępniany i odkrywany przez kolejne pokolenia. Zdjęcia Juliena Bryana (z 1946 roku), Leonarda Sempolińskiego, Zofii Chomętowskiej czy Marii Chrząszczowej pokazywane $\mathrm{w}$ galeriach nadal pobudzają do interpretacji. Czasem zaskakują motywami zapisanymi na barwnym nośniku, pozwalającym na inne niż zwykle odczytanie wizerunków. Magdalena Wróblewska, kuratorka współczesnej wystawy fotogramów Ewy Faryszewskiej, studentki ASP, która, zajmując się podczas powstania warszawskiego ratowaniem dzieł sztuki na Starówce, uwieczniła stolicę na barwnym negatywie, twierdzi, że zapisane na filmie fotograficznym różne mikrohistorie składają się na „wielowątkową biografię kliszy”[5]. Dodaje również: „Z tej perspektywy wydarzenia powstania warszawskiego to zaledwie początek jej [rolki filmu - przyp. M.K.C.] biografii, moment 'narodzin obrazu', równie istotne są późniejsze epizody, wskazujące na praktyki społeczne związane $\mathrm{z}$ fotografią - jej reprodukowanie, funkcjonowanie jako dokumentu lub ilustracji, włączenie do kolekcji muzealnej, wykorzystanie do pisania i wystawiania historii, a wreszcie jej przechowywanie i związany z nim proces niszczenia"[6]. Każdy zarejestrowany fragment archiwalnej taśmy winien więc być badany w stosownym kontekście. W niniejszym artykule pominę problemy degradacji nośnika obrazu i wynikające z tego konsekwencje[7], zwrócę natomiast uwagę na sposoby wykorzystywania wizerunku ruin w różnych, tekstualnych i narracyjnych celach, które niosą swoje indywidualne motywacje i „mikrohistorie”.

Wykorzystanie dokumentu filmowego dla przedstawienia zupełnie nowego w polskim pejzażu kulturowym motywu totalnie zniszczonej stolicy tłumaczyło kilka dość oczywistych argumentów. Po pierwsze - użytkowy charakter gatunku, powołanego do informowania oraz reprezentowania bardziej sił społecznych, niż indywidualnych[8]. Po drugie - wskazówki płynące z pism teoretycznych znaczącego i znanego już w Polsce brytyjskiego dokumentalisty i producenta Johna Giersona.

[3] S. Gebethner, „Warszawa oskarża” - wystawa w Muzeum Narodowym w Warszawie (3 maja 1945 28 stycznia 1946), „Rocznik Muzeum Narodowego w Warszawie" 1976, t. 20, s. 593-597.

[4] Ibidem.

[5] M. Wróblewska, Fotografie ruin. Ruiny fotografii 1944-2014. Muzeum Warszawy, Warszawa 2014, s. 6.
[6] Ibidem, s. 130.

[7] Zob. E. Wysocka, Wirtualne ciało sztuki. Ochrona $i$ udostepnianie dzieł audiowizualnych, Warszawa 2013.

[8] Por. M. Przylipiak, Poetyka kina dokumentalnego, Gdańsk 2000, s. 13-16. 
Współautor Żyjemy dzisiaj (1937) [9], którego idee w latach pięćdziesiątych kultywować będzie kreator polskiego dokumentu powojennego Jerzy Bossak, lansował tezę o pierwotnej konieczności skupienia twórcy na rzeczywistości widzialnej, autentycznej, na bazie której dopiero należy budować metaforę lub artystyczną interpretację zdarzeń. Reżyser wspomnianego tu obrazu, Alberto Cavalcanti, definiował zamierzenia przedwojennych filmów "giersonowskich” w sposób następujący: „U podstaw [...] było pragnienie udramatyzowania codzienności, tym samym przeciwstawienie się panującemu wówczas prądowi do dramatyzowania wydarzeń niezwykłych, niecodziennych; pragnienie zwrócenia oczu przeciętnego obywatela świata na te wydarzenia, które rozgrywają się przed jego oczyma, na jego własną historię" [10]. Ikonografia unicestwionego miasta w naturalny sposób wpisywała się w tę optykę. Jako trzeci mógł z czasem zostać włączony argument polityczny: zniszczenie przez Niemców urbanistycznego symbolu narodowego, jako retorsja na powstanie warszawskie, niosło niebezpieczeństwo kierowania oskarżeń pod adresem inicjatorów powstania oraz tendencyjnego gloryfikowania autorów odbudowy, którymi byli zarówno wszyscy Polacy, jak i - formalnie - reprezentanci komunistycznego reżimu.

Fundamentem polskiego dyskursu ruin jest 10-minutowa impresja Andrzeja Panufnika Ballada f-moll (1945), opatrzona w czołówce dopiskiem „transkrypcja filmowa”. Opowieść o zniszczonej stolicy (zdjęcia Adolfa Forberta[11]) została zestawiona do utworu Fryderyka Chopina. Autor filmu, w przyszłości światowej sławy dyrygent i kompozytor, okupację spędził w Warszawie[12], a po wyzwoleniu związał się na krótko z Wytwórnią Filmową Wojska Polskiego i krakowskim Instytutem Filmowym. Ballada f-moll została wyprodukowana wiosną 1945 roku przez Warsztat Filmowy Młodych w Krakowie. Wacław Świeżyński tak opisał tytuł:

\footnotetext{
Starannie dobrane kadry z zachowanego albumu przedwojennej Warszawy skontrastowano z filmowym i fotograficznym obrazem zdruzgotanej stolicy. $\mathrm{Na}$ ekranie korowód ruin, fantazyjnie poszarpane fragmenty murów wypalonych domów, szkielety wysadzonych w powietrze mostów, misternie wygięte wybuchami pocisków słupy gazowych latarń. Ruiny przeglądają się w nurcie Wisły, nad sylwetami wypalonych murów przebiegają pospiesznie chmury. Przelatujące ponad hałdami gruzów gołębie - to jedyny żywy element na tym cmentarzysku ruin[13].
}

[9] We Live In Two Worlds, real. Alberto Cavalcanti, Wielka Brytania 1937.

[10] Por. B. Michałek, Sztuka faktów. Z historii filmu dokumentalnego, Warszawa 1958, s. 25.

[11] I. Sowińska wyjaśnia: „Forbert nosił się z pomysłem stworzenia filmowej impresji, zmontowanej z obrazów zrujnowanej Warszawy, które zarejestrował tuż po wyzwoleniu miasta. Kilka z tych ujęć powraca w każdym z trzech filmów..." [chodzi o zrealizowane przez niego tytuły: Ballada f-moll, Zakazane piosenki i Suita warszawska - M.K.C.], por. I. Sowińska, Polska muzyka filmowa 1945-1968, Katowice 2006, s. 59.
[12] Podczas powstania warszawskiego skomponował jedną z najpopularniejszych do dzisiaj piosenek tego czasu - Warszawskie dzieci do słów Stanisława Ryszarda Dobrowolskiego. Po okresie pracy w stylistyce narzuconego w kraju muzycznego socrealizmu w roku 1954 wyemigrował do Wielkiej Brytanii i odniósł tam znaczące sukcesy.

[13] W. Świeżyński, Film dokumentalny, [w:] Historia filmu polskiego, red. J. Bocheńska i in., Warszawa 1974, s. 109-110. 
Wylewność recenzenta nie była bezpodstawna: film zaskakiwał doborem ujęć, geometryzującą kompozycją kadrów, szeroką możliwością interpretacji. Odkrywał olbrzymi potencjał tkwiący w nieruszonej dotąd przez twórców przestrzeni architektonicznego zniszczenia. Budził emocje i - w swoim czasie - zachęcał do osobistych refleksji i wspomnień. Na ekrany kin jednak nie wszedł. Zarzucono mu brak klarowności ideologicznej i optymizmu oraz niedostatki techniczne[14]. Co więcej, bardzo szybko zaginął i przez wiele lat uważany był za nieukończony i niemający kopii eksploatacyjnych[15].W roku 1980 zaskakująco wypowiedział się na jego temat Bossak:

Ale mój pierwszy warszawski film, Ballada f-moll z roku 1945, nigdy nie wszedł na ekrany, bo większość negatywów uległa zniszczeniu w laboratorium. Ocalałe fragmenty weszły później do Suity warszawskiej, pięknego filmu Tadeusza Makarczyńskiego. Jeszcze później włączyłem je do Powrotu na Stare Miasto[16].

Druga część wypowiedzi jest oczywista, ale przypisywanie sobie autorstwa Balladyf-moll jest rażącym nieporozumieniem, wynikającym może z faktu, iż Bossak pełnił wówczas funkcję kierownika artystyczno-programowego wojskowej wytwórni i łatwo dodawał sobie współautorstwo wielu projektów. Jolanta Lemann-Zajiček uważa, że o zatrzymaniu tytułu zadecydowała ambicjonalna rywalizacja filmowych liderów: Bossaka i Antoniego Bohdziewicza, który patronował tej realizacji[17].

Film Panufnika jest bardzo interesujący i - jak się okaże - stanie się wzorcowy dla przyszłych produkcji. Zawiera fragment wiersza Norwidowskiego Fortepianu Chopina, wykorzystuje detale zniszczeń, dym pożarów oraz kontrastowo sfotografowane obłoki płynące na niebie, które podkreślają siłę destrukcji; portretuje też elementy małej architektury, między innymi pomnik Mikołaja Kopernika. Ruchoma bądź przekrzywiona kamera wyraża niepokój, a szeroki obiektyw zniekształca - i tak już zdeformowaną - rzeczywistość. Rytm muzyki porządkuje narrację, niektóre obrazy powracają, w pewnym momencie przybierają formę dynamicznego, fotograficznego kolażu. Całość, zarówno wtedy, jak i teraz, ma potencjał pozwalający na zdobycie międzynarodowego uznania. Iwona Sowińska cytuje kompozytora zwracającego uwagę, że film został zatrzymany z powodów politycznych: „Przypomniano by sobie, że dla Rosji korzystne było pozostawienie powstańców własnemu losowi, doprowadzenie do zagłady miasta i wymordowania jego dzielnych obrońców przez Niemców”[18]. Również tej wersji nie

[14] Ibidem, s. 110.

[15] Stanowczo zaprzeczył temu Marek Hendrykowski: „Całkowicie nieprawdziwe jest twierdzenie zawarte w trzecim tomie Historii filmu polskiego (pod red. J. Toeplitza), iż dokument Andrzeja Panufnika Ballada f-moll nie został ukończony. Kopia tego niezwykle pięknego i poruszającego filmu spoczywała przez dziesiątki lat w zbiorach Archiwum WFDiF; odkryta na nowo kilka lat temu, została zaprezentowana w cyklu „Skarby Filmoteki” na antenie
TVP Kultura"; zob. M. Hendrykowski, Dokument po wojnie. Lata 1945-1955, [w:] Historia polskiego filmu dokumentalnego (1945-2014), red. M. Hendrykowska, Poznań 2015, s. 15-85.

[16] J. Bossak (wypow.), Ab urbe condita...

[17] Por. J. Lemann-Zajiček, Kino i polityka. Polski

film dokumentalny 1945-1949, Łódź 2003, s. 196-197.

[18] I. Sowińska, Polska muzyka filmowa 1945-1968,

Katowice 2006, s. 59. 
sposób odmówić prawdopodobieństwa: w filmie ukazany jest posąg Chrystusa ugiętego pod krzyżem, a kamera tak portretuje figurę, że jej ręka w oskarżycielskim geście skierowana jest na wschód. Mógł to być zamierzony zabieg realizatorów.

Ukrycie, czy też pominięcie, elegii Panufnika w obiegu publicznym wydaje się jednak zaskakujące[19]. Nawet bowiem, jeżeli film wydawał się zbyt pesymistyczny, od tematu nie sposób było uciec, co potwierdziła cała seria dość podobnych dokumentów, jakie pojawiły się wkrótce, zwłaszcza że życie całego państwa określił dekret Krajowej Rady Narodowej z 24 maja 1945 roku „O odbudowie m. st. Warszawy”, który powoływał trzy ciała urzędowe: Naczelną Radę Odbudowy m. st. Warszawy, Komitet Odbudowy Stolicy i Biuro Odbudowy Stolicy. Każde z nich działało dynamicznie, zgodnie z przyjętym przez Naczelną Radę zadaniem mobilizacji zasobów duchowych i materialnych całego Narodu dla dzieła odbudowy stolicy. Dla ogółu Polaków odbudowa była priorytetem bezdyskusyjnym, do miasta licznie i chętnie zjeżdżały wycieczki włączające się w prace przy odgruzowywaniu. 3 lipca 1947 roku dekret KRN został przekształcony w ustawę „O odbudowie m. st. Warszawy”, a w 1948 roku utworzono Społeczny Fundusz Odbudowy Stolicy. Na odbudowę przeznaczono specjalny podatek, którym obciążono wszystkich pracujących. Informacje o odbudowie regularnie pojawiały się w gazetach i radiu, a kronika filmowa realizowała cykl Biuletyn Odbudowy Stolicy.

W roku 1945 roku do rozpowszechniania trafił natomiast 15-minutowy reportaż Stanisława Urbanowicza Budujemy Warszawę. Reżyser, członek Czołówki Filmowej WP, rozpoczął film od zaczerpniętych z niemieckich kronik ujęć hitlerowskich dowódców decydujących o zniszczeniu miasta. Artyleryjskie działa wycelowane są w pomnik Syrenki, do ataku startują bombowce, eksplozje pocisków rujnują domy („Zapamiętajcie ten obraz. Tak umierała stolica”), płomienie miotaczy zapalają budynki. Płonie wnętrze kościoła Świętego Krzyża. Figura ukrzyżowanego Chrystusa leży na bruku. Wokół niej ludzkie zwłoki i zniszczona tablica z nazwą pokonanej stolicy. Kolumny cywilów opuszczają domy („wygrzebani spod gruzów pogrobowcy milionowego miasta"). Dymy pożarów zasnuwają ujęcia wykonane z lotu ptaka. Zbombardowane ciągi kamienic przywodzą na myśl nietrwałe budowle z piasku. Przechodniów straszą pozbawione mieszkań pierzeje domów („A kiedy nadeszło wyzwolenie, przywitała żołnierzy wolności cmentarna pustka ruin”). Komentarz jest oszczędny, gdyż kadry pełne są symbolicznych śladów zagłady. Uszkodzone fasady dominują w pustce otoczenia, miasto jest wymarłe, co podkreśla żałobna muzyka Romana Palestra. Kamera długo pokazuje podziurawione pociskami pozostałości świątyń, przygląda się cokołom, z których strącono bohaterów, obserwuje zerwany most, przerwane tory kolejowe, szkielety

[19] Sowińska podkreśla, że „przepustki na ekran” nie gwarantowała nawet muzyka Chopina. Por. I. Sowińska, Chopin idzie do kina, Kraków 2013, s. 245. 
hal przemysłowych. Treść filmu zmienia się w dziesiątej minucie, gdy na gruzach pojawiają się architekci, którzy przygotowują nowe projekty urbanistyczne i architektoniczne rekonstrukcje („duma i ozdoba Warszawy wrócą do dawnej świetności”). Komentarz rozbudza nadzieję: „Rośnie wizja nowej Warszawy, świadectwo woli narodu, który nie załamuje rąk w bezsilnej rozpaczy, ale buduje na gruzach nowe, wspanialsze życie". Tłumy cywilów ruszają do odbudowy, rozbierają pozostałości budynków, odzyskane cegły przekazują sobie w łańcuchu rąk. Wre praca na budowach („piaskarz warszawski, drwal podhalański, hutnik ze Śląska, szklarz z Piotrkowa, cała Polska buduje Warszawę”), co podkreśla dynamiczna, marszowa muzyka i komentarz: „Chwała narodowi, co na dymiącym pogorzelisku buduje stolicę swej wielkości”. Pracują maszyny, miasto ożywa w szybkim, tak zwanym warszawskim tempie. Zmieniają się plany ujęć, kamera podąża w górę za rosnącymi murami, wszystkiemu przygląda się nienaruszona Syrenka, a słowa pieśni zakończenia proszą: Tak nam dopomóż Bóg. W udanym i ciekawym filmie łączą się razem wspomnienie historii, przywiązanie do tradycji, tęsknota za niegdysiejszym pięknem i nadzieja na jego rychłe odtworzenie. Oszczędny w emocje, powściągliwy realizm odbudowy zniszczeń mógł napawać optymizmem, integrować przy wspólnej pracy i łączyć wokół patriotycznych wartości.

Równie interesujący jest Most, 9-minutowy reportaż Bossaka (1946), będący jednym z najważniejszych - choć niesłusznie pomijanych - obrazów tego twórcy, wyrażający pełnię jego programowych zasad. Relacja z odbudowy mostu Poniatowskiego rozpoczyna się ujęciami zniszczonej Warszawy w dniach wyzwolenia. Komentarz (scenarzystą jest Bossak, autorem zdjęć Karol Szczeciński) podkreśla wolę życia u powracających ludzi: „Prezydent i ministrowie błądzą pustymi ulicami, nasłuchują, czy bije serce Warszawy". Gdy zapada decyzja o odbudowie mostu, na ekranie ruszają prace. $Z$ powalonych do rzeki przęseł wyrasta nowa konstrukcja, którą przygotowują hutnicy w całym kraju. Bez patosu i propagandowego zadęcia kamera pokazuje wysiłek ludzi, dokumentuje trudności przy pracy, tworzy konsekwentny styl fotogenii nitów i poezji rusztowań, bliższy estetyczno-rytmicznym doświadczeniom kinematografii dwudziestolecia międzywojennego, niż mającym się dopiero pojawić dominantom socrealizmu. Moment oddania konstrukcji do użytku reżyser zestawia z ujęciami ruchu miasta w odbudowie:

Ten most jest takim samym fenomenem, jak cała Warszawa. To miasto skazane na zagładę, zamienione w zwały gruzów i ruin, żyje. Nie tylko żyje, ale tętni bujnym, wspaniałym, prawdziwie młodym życiem.

Reżyser obwieszcza narodziny nowego porządku. Samochody na skrzyżowaniu Marszałkowskiej i Alei Jerozolimskich, kierująca ruchem milicjantka, tramwaje na moście i tłumy przechodniów na ulicach, wszystko to wyraża wiarę w odrodzenie się po tragedii. Dla Bossaka natomiast obrazy przywróconego życia mogą być formą oczyszczenia się 
po traumie, swoistym reżyserskim katharsis: zaledwie dwa lata wcześniej z prawego brzegu Wisły obserwował przecież walczące, a następnie metodycznie niszczone przez hitlerowców miasto. Takie doświadczenie, również dla innych realizatorów, musiało być rodzajem niezatartego piętna. Twórca Mostu wspominał:

[...] będąc w Lublinie szykowaliśmy się na Warszawę. Na mapie, na planie Warszawy, robiliśmy kreski. Szopena - tu będzie atelier, Leszczyńska - laboratorium, Wolska - atelier, Trembacka - atelier. I tam będziemy pracować. I nie zapomnę momentu, kiedy jestem na Saskiej Kępie i, patrząc na drugą stronę Wisły, widzę, że to są marzenia, które się nie zrealizują, ponieważ to płonie. Ponieważ Warszawa - tak jak Führer powiedział - staje się punktem geograficznym. Kategorią związaną z historią, a nie realnym miastem. Czyli Warszawa przestaje istnieć[20].

Możliwość odbudowy była więc siłą napędową dla społeczeństwa i tłumaczyła również entuzjazm filmowców. Oryginalny Most pozwalał zaprzeczyć niedawnemu zwątpieniu, a widzów zarażał optymizmem.

Otwartą drogę do kin miała również Suita warszawska (1946) Tadeusza Makarczyńskiego. Reżyser, niedawny asystent Bohdziewicza w Instytucie Filmowym, wiosną zrealizował 18-minutową impresję na temat zdruzgotanego, ale podnoszącego się ze zgliszcz miasta. Ilustrowana muzyką Witolda Lutosławskiego opowieść miała kompozycję trójczłonową: Adagio - Klęska, Andante - Powrót do życia, Allegro Wiosna warszawska. Jak po latach wspominał Makarczyński, film

[...] był efektem wrażenia, jakie zrobiła na mnie Warszawa, gdy przyjechałem tu w połowie roku 1945. Było to moje miasto, miasto mojej młodości, studiów. Nie widziałem Warszawy w czasie wojny - przebywałem wtedy w Zagłębiu i Krakowie. Warszawa 45 zrobiła na mnie niezapomniane, niezatarte wrażenie. Chodziłem po niej odurzony i zauroczony. Było to i jest zjawisko jedyne w swoim rodzaju: fenomen życia, jego zwycięstwa nad śmiercią[21].

Pierwsza część filmu różni się od pozostałych. Rozpoczyna ją ujęcie figury Chrystusa trzymającego krzyż na tle ruin Krakowskiego Przedmieścia. Świat wydaje się nierealny, przekrzywiona kamera obserwuje strzępy zabytków, zdeformowane budowle widzimy jakby przez łzy, które zamazują wyrazistość konturów (oryginalne zdjęcia Adolfa i Władysława Forbertów), upiornym oczodołom kamienic przygląda się posągowy Kopernik z bezużytecznym astrolabium w dłoni. Nad jego głową w przyspieszonym tempie przesuwają się kontrastowo sfotografowane obłoki, które przypominają ciemny dym pożarów. Ujęcia znajomych form (zwieńczenie hotelu Bristol, pozbawiona dłoni figura Matki Boskiej z Dzieciątkiem bez głowy, kolumny świątyń wznoszące się donikąd) są odrealnione, nie ludzkie, nie z antropologicznego świata. Wykrzywione słupy oświetleniowe trwają przed niegdysiejszymi do-

[20] Wypowiedź pochodzi z rękopisu: Z. Czeczot-Gawrak, Bruliony rozmów z pionierami kroniki i dokumentu PKF/WFD prowadzone w latach 1978 i 1979, s. 15, w zbiorach Instytutu Sztuki PAN.
[21] T. Makarczyński (wypow.), Ab urbe condita..., [w:] Z. Czeczot-Gawrak, op.cit. 
mami, w których nikt nie mieszka, a pozbawione szyb latarnie gazowe nędznie zwisają z resztek murów. Jest cisza, nie ma życia. Tylko czas płynie, o czym przypominają płynące chmury.

Przedstawione ujęcia tworzą archetyp urbanistycznej śmierci. Będą przywoływane i cytowane przez wiele lat, między innymi w kronikach i okolicznościowych składankach Chwila wspomnień (reż. J. Bossak, W. Kaźmierczak, L. Perski, 1964); dosłownie zostaną przytoczone przez kilku kolejnych realizatorów. Do tego stopnia wiernie, iż zasadne stanie się pytanie o ewentualne naśladownictwo autora Suity... przez niektórych twórców. Kolejne części filmu wypełnia optymizm. W drugiej, na Stare Miasto wracają mieszkańcy, dym leci z prowizorycznego komina, pomiędzy ruinami odradza się życie: kobieta porządkuje prymitywne lokum, mężczyzna niesie fragment łóżka, wśród gruzów schnie pranie, lecą gołębie. Rusza praca: murarze układają cegły, rosną mury, stają rusztowania, są już nowe bloki, a nawet całe osiedle. Parterowa Marszałkowska tętni życiem: przechodnie spieszą wśród pierwszych sklepów, oczy cieszy kwiaciarnia, obok milicjanta kierującego ruchem na skrzyżowaniu (to ujęcie będzie powtarzane w przyszłości wielokrotnie) jadą samochody, tramwaje i trolejbusy (również i te ujęcia powrócą). W części trzeciej zakwita zieleń. Kwiaty rosną wśród powstańczych mogił, bawią się dzieci, wycieczka zwiedza miasto, ludzie tańczą na podmiejskiej zabawie. Zamiast na gruzach, kamera skupia się teraz na radosnych twarzach mieszkańców. Miasto żyje, ludzie spacerują przy fontannie, bawią się na karuzeli. By oddać harmonię tego życia, Lutosławski podczas realizacji sam ustalał rytm ruchów dorożkarza i zamiatacza ulic, którzy pojawiali się przed kamerą.

Film zdobył międzynarodowe uznanie: pokazany został w 1946 roku w Paryżu i na festiwalu w Cannes, wiosną następnego roku pojawił się w telewizjach francuskiej i amerykańskiej, w Białym Domu zobaczył go prezydent Harry Truman[22]. Realizatorzy (montaż Wacława Kaźmierczaka) zdołali płynnie przejść w diegezie filmu od deformacji i dezintegracji (martwota ruin i rozczłonkowanie miasta, a zarazem żywiołowy ruch obłoków), poprzez nadzieję wyrażoną $\mathrm{w}$ tworzeniu nowych struktur (powrót życia w ruiny, odtworzenie architektury, budowa nowej tkanki urbanistycznej), do wrażenia spełnienia i harmonii uzyskanych dynamiką ruchów (taniec, woda płynąca z fontanny, zabawa na karuzeli). Doświadczenie upadku cywilizacji i kulturowego zniszczenia przeobraził Makarczyński w radosną nadzieję nowego otwarcia.

Antropologiczna lektura powojennych ruin znajdowała różnych interpretatorów. Wczesną jesienią 1947 roku Wojciech Has i Stanisław Różewicz zrealizowali film Ulica Brzozowa (1947). Tematem 9-minutowej opowieści jest powrót do życia niewielkiej ulicy Starego Miasta. Film rozpoczyna się ujęciem milicjanta kierującego ruchem na skrzy-

[22] Materiały filmowe w zrujnowanej Warszawie w 1946 roku realizowali też operatorzy kronik zagranicznych, między innymi francuskiej Pathé. 
żowaniu Marszałkowskiej i Alei Jerozolimskich („po arteriach wielkiego miasta mkną autobusy, taksówki, tramwaje"). Następnie oglądamy wystawy sklepowe i żywy ruch uliczny, widzimy ujęcia odbudowanego już centrum. Po tym pojawia się ujęcie tablicy z nazwą ulicy Brzozowej („ale istnieje Warszawa inna, Warszawa cicha i samotna, lecz równie piękna i droga"), i kamera kieruje się na ścieżkę wydeptaną wśród ruin, zagląda w opustoszałe zakamarki Starówki. Widzimy dym lecący z komina, pranie suszące się wśród gruzów, nieczynne latarnie, bawiące się dzieci („mała Hania zatęskniła za słońcem. Z samego rana rozpoczyna podróż wśród ruin, zdawałoby się - wymarłych"). W okolicy dzieci jest więcej: kamera podgląda sceny zabawy, a potem dorosłych przy pracy („warszawiacy to naród twardy i nieustępliwy”), zagląda do prymitywnych mieszkań. Realia przekonują, że trzeba odbudować ruiny: uzupełnić schody prowadzące donikąd, wstawić okna, otworzyć sklepy. W zamieszkanych piwnicach chłopiec konstruuje model samolotu. $\mathrm{Na}$ dachu jednego z bloków staje wiecha („niedługo przeniosą się do słonecznych domów wszyscy mieszkańcy piwnic i ruin”). Brzozowa powraca do życia.

Film zatem oswaja ruiny. Nie są one już symbolem klęski, ale dowodem siły i niezłomności. Interpretacja Hasa zawiera wiarę w potęgę kondycji ludzkiej i niepowstrzymaną witalność życia. Wszystko pokazane jest w wymiarze kameralnym, a jednak urasta do rangi symbolu: skoro życie wraca na Starówkę, to z pewnością wróci do innych, podobnych miejsc w kraju. Wyraziste przesłanie nie jest przy tym nachalne: nie ma w nim ani hurraoptymizmu, ani urzędowej deklaratywności, ani propagandowego entuzjazmu. Jest raczej intymny i osobisty punkt widzenia.

Gdy około roku 1948 komuniści rozpoczęli w Polsce ofensywę upolityczniania każdej sfery życia publicznego, zmieniła się również narracja dotycząca ruin. Na pierwszy plan wyszła perswazja produkcyjna i agitacja zimnowojenna. Ikonografia ruin wykorzystywana była do zwiększenia wydajności pracy: to, co zniszczone, trzeba przywrócić do świetności, a w miejscu gruzów stworzyć osiedla mieszkaniowe zadekretowane w trzyletnim Planie Odbudowy Gospodarki. Ten wątek kronika filmowa powtarza w meldunkach o pracy murarzy i całego przemysłu. Wizerunek ruin (także warszawskich) wykorzystuje natomiast do interpretowania politycznego konfliktu między Wschodem a Zachodem, nakręcając na ekranie psychozę na temat wojny w Korei. Tę zaś propagandowo przedstawia poprzez resentymenty obrazów niedawno zakończonej wojny w Europie: nalotów, bombardowań, walących się domów i ludzi opłakujących swoich bliskich pośród zgliszcz. Ruiny stają się synonimem „amerykańskiej agresji, imperialistycznych knowań, polityki prezydenta Trumana" i zapowiedzią kolejnej wojny, której wizją radzieccy komuniści zmuszają zależne kraje do uległości. $\mathrm{O}$ ile do tej pory ruiny służyły odreagowaniu traumy i oswojeniu się z powojennym szokiem, ale też ukazaniu prawdy historycznej i sformułowaniu oskarżeń wobec Niemców, teraz stały się budulcem strachu 
i siłą napędową międzynarodowej agresji politycznej. „Genowefo Marcinkowska, czy wiesz, co oznacza twój podpis?” - pyta lektor bohaterkę inscenizowanego wydania specjalnego PKF My niżej podpisani (1950), które nakłaniało do popierania antyamerykańskiego tak zwanego Apelu Sztokholmskiego. „Przestałaś, Genowefo, wypatrywać nieba, czy nie pojawi się samolot wroga" [23] - odpowiadał komentarz, gdy na ekranie migały spadające bomby, a pierzeja domów waliła się na leżące w wózku niemowlę. Traumatyczne resentymenty były silne - i chętnie używane. Pojawiały się w wielu tytułach: Ludzie wybierają życie (reż. Bronisław Wiernik i Rafał Praga, 1950), Korea oskarża (1950) i Go Home. Wracaj do siebie (1952) - te dwa wyreżyserowane przez Wiernika, wykorzystujące jako motyw zgliszcza azjatyckich wiosek, oraz Pokój zwycięży (reż. J. Bossak, 1950). Ten ostatni tytuł (podpisany pseudonimem Jerzy Szelubski) był 20-minutową montażową składanką, wykorzystującą wcześniejsze materiały PKF i kronik zagranicznych, i epatował stalinowską propagandą w promowaniu I Polskiego Kongresu Pokoju. Na ekranie pojawiały się niemieckie samoloty („Przed jedenastu laty bombowce hitlerowskie zdradziecko napadły na Polskę"), a następnie widzowie oglądali maszyny amerykańskie zrzucające bomby, ich wybuchy, przerażenie ofiar i łuny pożarów („Dziś bombowce amerykańskie podpalają miasta i wsie Korei"). Destrukcja budynków stawała się zrozumiałym dla wszystkich chwytem retorycznym. Upadek cywilizacji, pokazany przez Panufnika i Makarczyńskiego w wymiarze estetycznym, tutaj przybierał wymiar polityczno-ideowy. Ruiny stawały się natomiast znakiem ostrzeżenia, mobilizacji, i - bez wątpienia - narzędziem manipulowania świadomością mas. Były częścią strategii.

Elementem strategii, chociaż już innej, bo związanej zarówno z powrotem stolicy do dawnej świetności, jak też z pochwałą dokonań komunistycznej władzy, jest Powrót na Stare Miasto (reż. J. Bossak, 1954) [24]. To 20-minutowy dokument rekonstrukcji zabudowań stołecznej Starówki, pokazany od momentu powrotu pierwszych Robinsonów na pole ruin, po uroczyste oddanie do użytku zrekonstruowanej dzielnicy[25]. Początek filmu tworzą obrazy zniszczeń, które podkreśla elegijna muzyka Stanisława Skrowaczewskiego. Widzimy apokaliptyczne pobojowisko - kikuty domów, szkielety latarń; dawną urbanistyczną przeszłość przypomina zachowany pomnik Kopernika („Tyle zostało z dawnej Warszawy"). Monument trwa, mimo płynącego czasu, jaki odmierzają pokazane w przyspieszonym tempie obłoki przesuwające się na niebie. „Jakiej siły trzeba, żeby wróciło tu życie?” - pyta narrator, a realizatorzy odpowiadają: „siły zapału i ofiarności wszystkich Polaków”. Ilustrują to obrazy zastępów młodzieży z kilofami, sceny wyburzania pokazane w rytmie pieśni rewolucyjnych, praca architektów

[23] M. Cieśliński, Piękniej niż w życiu. Polska Kronika Filmowa 1944-1994, Warszawa 2006, s. 23.

[24] Powrót na Stare Miasto powstał w wyniku zlecenia przez Komitet Centralny PZPR realizacji filmu z okazji 10-lecia Polski Ludowej.
[25] Autorem zdjęć jest Franciszek Fuchs, wcześniej operator Wytwórni Filmowej Wojska Polskiego. 
i robotników. Kamera dokumentuje szybkie tempo robót, przygląda się odtwarzanym zdobieniom i detalom kamienic („rodzi się jej nowa sylweta i nowe piękno"), pokazuje miasto z lotu ptaka, w tym budowany Pałac Kultury i Nauki. Finałowe sceny oglądamy w kolorze: 22 lipca prezydent Bierut uczestniczy w radosnym przekazaniu Starówki do użytku. Odbywa się zabawa, nad dachami kamienic dymią kominy. Fragmenty wydają się znajome. Jest Kopernik na postumencie, te same, co w Suicie warszawskiej kadry wypalonych kamienic, wygiętych słupów ulicznych i rozbitych latarń. Tak samo szybko płyną obłoki. Może jest to zauroczenie estetyczną wizją Makarczyńskiego, a może nieodparta sugestia biorąca się z fundamentalnego wizerunku stworzonego przez poprzedników. W odróżnieniu od Suity... tutaj jednak uderza propagandowy entuzjazm, jednowymiarowość rzeczywistości i deklaratywny opis zdarzeń. Sens filmu zawarty jest w jednakowym stopniu w obrazie, co w narzucającym interpretację komentarzu.

Uśmiechu brakuje natomiast $\mathrm{w}$ innej wariacji na temat ruin. Warszawa 1956 (reż. Jarosław Brzozowski i Jerzy Bossak, 1956) wpisuje się w nurt czarnej serii dokumentu kształtem antytezy. W tym filmie najpierw oglądamy odbudowaną Warszawę: nowe bloki, arterie ulic, po których kursują trolejbusy (ujęcia wykorzystane już wcześniej), zadbane elewacje Starówki i Pałac Kultury, przed którym tętni ruch miasta. Po tym widzimy nieodległy, ale inny zaułek, a w nim resztki zbombardowanych w czasie wojny kamienic. Nad ich mieszkańcami zwisają fragmenty gzymsów, ciężkie bloki kamienne chwieją się na wietrze, grożąc śmiercią, straszą czeluści zerwanych schodów i balkony bez balustrad. W tej przestrzeni toczy się życie: fruwają gołębie, schnie pranie, dzieci puszczają samoloty z papieru, kobieta pochyla się nad balią. Jej małe dziecko, jeszcze osesek, niepostrzeżenie samo oddala się w ruiny. Co mu się wydarzy? Tragedia jest o krok. Puentą oskarżycielskiego filmu jest roznoszący się wśród murów krzyk dziecka. Urbanistyczne szczątki ponownie stają się apelem i oskarżeniem, tym razem w publicystycznym kontekście: ruiny trzeba zlikwidować, a ludzi przeprowadzić do nowych mieszkań. Dominuje jednak wykorzystane już wcześniej tło społeczne (bawiące się dzieci, domowa codzienność) oraz estetyczny kontrast nowej i starej architektury (piękne domy i fragmenty ruder). Pojawiająca się w zakończeniu nieczynna latarenka ścienna nieodparcie przywodzi na myśl oberwaną tablicę z ulicy Brzozowej.

Obrazy ruin - chodzi mi zawsze o przedstawienia autentycznych gruzów Warszawy - pełnią w kinie dokumentalnym różne funkcje. Są antropomorficznymi metaforami, wyrażając psychiczną kondycję postaci pojawiających się na ekranie. Określają stosunek realizatorów do rzeczywistości, kiedy jej zdeformowane struktury, nieraz zupełnie pozbawione pierwotnych kształtów, przywodzą na myśl przede wszystkim chaos, dezorientację i rodzą trudność opisu. Definiują świat przedstawiony jako przestrzeń doznanej traumy, a zarazem dowód oskarżenia przeciwko jej sprawcom. Są też tworzywem narracji, gdy pojawiając się jako element kontrastu lub antytezy, organizują konstrukcję filmów 
prowadzących do konkretnych wniosków lub publicystycznej agitacji. Oprócz tego niosą znaczenie estetyczne zawarte $\mathrm{w}$ ich materialnej strukturze, fakturze, barwie (lub jej odcieniach) i odniesieniach do pierwotnie wypełnianych funkcji. Użyteczność formalna i tekstualna urbanistycznych artefaktów jest zaskakująco duża, destrukcja staje się elementem kreacji, a jej przykłady - efektywnym budulcem znaczeń i sensów.

W omawianym okresie architektoniczne ruiny stolicy były w filmie dokumentalnym wykorzystywane na różne sposoby. Motywy zniszczonych budowli budziły nostalgię (Warszawa, real. Ludwik Perski, 1952-1954), były pretekstem do uprawiania bieżącej publicystyki (Rok 1946, reż. Jerzy Bossak, 1946), oraz okazją do żegnania ofiar wojny (Teatr mój widzę ogromny, real. Jerzy Zarzycki i Jan Marcin Szancer, 1946). Obrazy architektonicznej destrukcji wykształciły retorykę, której przykłady omówiłem w tekście.

Bossak J. (wypow.), Ab urbe condita..., „Film” 1980, nr 3

B I B L I O G R A F I A

Cieśliński M., Piękniej niż w życiu. Polska Kronika Filmowa 1944-1994, Warszawa 2006

Czeczot-Gawrak Z., Bruliony rozmów z pionierami kroniki i dokumentu PKF/WFD prowadzone w latach 1978 i 1979. Rękopisy. Instytut Sztuki Polskiej Akademii Nauk w Warszawie

Gebethner S., „Warszawa oskarża” - wystawa w Muzeum Narodowym w Warszawie (3 maja 1945 - 28 stycznia 1946), „Rocznik Muzeum Narodowego w Warszawie" 1976, t. 20

Hendrykowski M., Dokument po wojnie. Lata 1945-1955, [w:] Historia polskiego filmu dokumentalnego (1945-2014), red. M. Hendrykowska, Poznań 2015

Lemann-Zajiček J., Kino i polityka. Polski film dokumentalny 1945-1949, Łódź 2003

Michałek B., Sztuka faktów. Z historii filmu dokumentalnego, Warszawa 1958

Przylipiak M., Poetyka kina dokumentalnego, Gdańsk 2000

Sowińska I., Chopin idzie do kina, Kraków 2013

Sowińska I., Polska muzyka filmowa 1945-1968, Katowice 2006

Świeżyński W., Film dokumentalny, [w:] Historia filmu polskiego, red. J. Bocheńska $\mathrm{i}$ in., Warszawa 1974, s. 109-110

White H., Historiografia i historiofotia, przeł. Ł. Zaremba, [w:] Film i historia. Antologia, red. I. Kurz, Warszawa 2008, s. 117-127

Wróblewska M., Fotografie ruin. Ruiny fotografii 1944-2014. Muzeum Warszawy, Warszawa 2014

Wysocka E., Wirtualne ciało sztuki. Ochrona i udostępnianie dzieł audiowizualnych, Warszawa 2013 